\title{
Upute biskupima sv. Alfonza Marije de Liguorija
}

\author{
BORIS VULIĆ*
}

\begin{abstract}
UDK: 27-36-722.52 Liguori, A. • Izvorni znanstveni rad Primljeno: 25. rujna 2017. • Prihvaćeno: 18. lipnja 2018.
\end{abstract}

* Doc. dr. sc. Boris Vulić, Katolički bogoslovni fakultet u Đakovu Sveučilišta J. J. Strossmayera u Osijeku, P. Preradovića 17, 31400 Đakovo, Hrvatska, vulic@me.com
Sažetak: Biskupska služba prva je, najvažnija i najodgovornija služba u Crkvi. Zbog toga je predmet promišljanja teologa i duhovnih pisaca, medu kojima se ističe sv. Alfonz Marija de Liguori (18. st.). Članak, nakon kratkoga životopisa i presjeka crkvenih prilika de Liguorijeva vremena, prikazuje njegove upute biskupima kako dobro upravljati svojom Crkvom. Riječ je o najvažnijim brigama svakoga biskupa (sjemenište, ređen$i c i$, svećenici, župnici, vikar i najbliži suradnici te redovnice) $i$ najučinkovitijim biskupovim sredstvima za dobro upravljanje svojom Crkvom (molitva, dobar primjer, rezidiranje, vizitacije, pučke misije, sinoda, savjetovanje, privatne audijencije $i$ opomene). Zaključne misli pokazuju da se figura biskupa $i$ njegova služba upravljanja Crkvom, opisane u sv. Alfonza, pokazuju kao pozornosti vrijedan doprinos $i$ za suvremenu obnovu biskupske službe te rast u svetosti biskupa Kristove Crkve, a time i cijeloga Božjega naroda. Tu se posebno izdvaja biskupova obveza donošenja informiranih odluka na temelju kazivanja istine te se ukazuje na razliku doušnika i osoba istine.

Ključne riječi: Alfonz Marija de Liguori, biskupi, upravljanje biskupijom, obnova biskupske službe, odlučivanje, kazivanje istine, svetost.

\section{Uvod}

Sv. Ignacije Antiohijski, poput glasnogovornika prve $\mathrm{Cr}$ kve, biskupa opisuje kao sliku (ikonu) Boga Oca, ${ }^{1}$ a II. va-

${ }^{1}$ Usp. IGNACIJE ANTIOHIJSKI, Epistula ad Trallianos, 3, 1, u: SC, 10bis, 96, citirano prema: Katekizam Katoličke Crkve, Zagreb, 2016., br. 1554, bilj. 33 . 
tikanski koncil podsjeća da prvo mjesto među službama u Crkvi pripada biskupima koji, po apostolskom nasljedstvu, »imaju mladice apostolskoga sjemena $\ll$ te zajedno s prezbiterima i đakonima služe zajednici stojeći »mjesto Boga na čelu stada kojemu su pastiri, i to kao učitelji nauka, svećenici svetoga bogoslužja i služitelji u upravljanju «. Zato $\gg$ tko njih sluša, sluša Krista, a tko njih prezire, prezire Krista i Onoga koji je Krista poslao (usp. Lk 10, 16) $\ll^{2}$

Najjednostavnije i istodobno najtočnije rečeno, biskupi su nasljednici apostola. To je najkraća definicija u teološkim knjigama i u teološkom studiju. U samo dvjema riječima moguće je zgusnuti srž prve i najvažnije službe u Crkvi. Međutim te nam dvije riječi službu biskupa predstavljaju i kao najodgovorniju, a time i najtežu službu u Crkvi. Zato su mnogi koji su je trebali prihvatiti u sebi vodili pravi duhovni boj s vlastitom nemoći i poniznošću spram odgovornosti te službe. Možemo reći da je ta borba važan znak prikladnosti izabranoga za biskupa jer se već tu pokazuje kako je potrebna golema samosvijest onoga koji će biti posvećen za biskupa o tome što je biskup za Kristovo Tijelo koje je Crkva. Sv. papa Ivan XXIII. u svoj će dnevnik 1925. godine, nekoliko dana prije negoli će biti zaređen za biskupa, zapisati sljedeće:

»Nisam tražio ni želio tu novu službu, ali me je Gospodin izabrao s tako očitim znacima svoje volje, da sam smatrao kako bih svojim protivljenjem učinio težak prekršaj. Dakle, on je dužan da pokrije moju bijedu i da nadopuni moje nesposobnosti. To me jača te mi daje mir i sigurnost. Bit ću biskup: dakle nema više vremena za pripravu. Moj stalež je stalež već 'postignutog' savršenstva, a ne savršenstva 'koje valja postići. 'Biskupski stalež, veli sv. Toma, je po svojoj naravi stalež savršenstva, jer spada na učiteljstvo savršenosti.' Kakva li užasa za mene koji se osjećam i jesam tako nevoljan i pun pogrešaka u mnogim stvarima. Kakva li razloga da se uvijek držim ponizan, ponizan, ponizan! $\ll^{3}$

Kako bi biskupi bili manje nevoljni i kako bi činili manje pogrješaka, mnogi su duhovni učitelji osobitu pozornost posvećivali biskupskoj službi. Među njima se ističe sv. Alfonz Marija Liguori, jedan od najpoznatijih asketskih pisaca, koji je u baštinu biskupima predao svoje djelo naslovljeno Korisne upute biskupima za praksu dobrog upravljanja njihovim Crkvama. ${ }^{4}$ Te ćemo upute prikazati i analizirati u ovome radu, a prije toga ćemo ukratko predstaviti sv. Alfonza te skicirati kontekst dušobrižništva njegova vremena.

${ }^{2}$ DRUGI VATIKANSKI KONCIL, Dogmatska konstitucija o Crkvi »Lumen gentium $\ll(=\mathrm{LG}), \mathrm{u}$ : ISTI, Dokumenti, Zagreb, ${ }^{7} 2008$., br. 20.

${ }^{3}$ IVAN XXIII., Dnevnik duše i ostali pobožni spisi, Zagreb, 2009., 383., br. 632. Slično i u: J. RATZINGER, Moj život. Autobiografija, Split, 2005., 129s.

${ }^{4}$ A. M. DE LIGUORI, Riflessioni utili a' vescovi per la pratica di ben governare le loro Chiese, Todi, 2015. (= Riflessioni utili a' vescovi). 


\section{O sv. Alfonzu Liguoriju (1696. - 1787.), biskupu i crkvenom naučitelju}

Alfonz Marija Liguori rođen je 27. rujna 1696. godine u selu Marianella u blizini Napulja. ${ }^{5}$ Bio je sin pobožne majke i velikog admirala Napuljskoga Kraljevstva, koji je odredio da svestrani Alfonz treba postati odvjetnik. Alfonz s nepunih 17 godina postiže doktorat iz kanonskoga i civilnoga prava, ali ubrzo napušta zanimanje odvjetnika razočaran nepoštenjem koje je vladalo u tim krugovima. Svakodnevna molitva, pohodi crkvama, samoća i ljubav prema siromašnima i bolesnima pomažu mu da u svećenstvu pronađe svoje novo i trajno zvanje. Svećenikom postaje 21. prosinca 1726. godine, u svojoj 31. godini. Isprva je na službi bio u Napulju te se odmah odlikovao izvanrednim dušobrižništvom, vrlinom koja će ga pratiti do kraja života. Posebno mu je bilo stalo do vjerske pouke svih slojeva naroda. Propovijedao je i primao sve, bez ikakve razlike. Izmoren djelovanjem, odlazi na bolovanje te donosi životnu odluku da će se posve posvetiti naviještanju Kristova otkupljenja i istinskoga čovjekova spasenja.

Zato je 1732. godine, sa svojih 36 godina, osnovao Red Presvetog Spasitelja, koji će poslije papa Benedikt XIV. (1740. - 1758.) preimenovati u Red Presvetog Otkupitelja (redemptoristi). Prva središta misijskoga djelovanja Alfonza i njegova reda bila su zapuštena sela Napuljskoga Kraljevstva, a umijeće jednostavna i jasna propovijedanja kroz formu pučkih misija odmah je bila prepoznato. Isti stil odiše i mnoštvom asketskih priručnika, kao i djelima iz moralne teologije, koja je Alfonz pisao ponajprije za potrebe svoga reda. U trideset godina misijskoga propovijedanja (1732. - 1762.) postao je jedan od najplodnijih i najčitanijih duhovnih pisaca sve do danas. ${ }^{6}$ Osobito se nadahnjivao duhovnošću sv. Terezije Avilske, sv. Ivana od Križa, sv. Ignacija Lojolskoga i sv. Franje Saleškoga te apostolatom sv. Karla Boromejskoga i sv. Filipa Nerija.

U svojoj 66. godini, upravo kad je osjećao da su mu snage oslabile i da mu se bliži kraj života, Alfonz je pozvan na novi zanos u svom životu, za njega osobno posve neočekivano i neželjeno, gotovo šokantno - trebao je postati biskup. Tomu se Alfonz isprva pokušao oduprijeti pozivajući se na svoje slabo zdravlje te na pravilo svoga reda o neprihvaćanju časti, dobara i službi. Međutim papa Klement XIII. (1758. - 1769.) bio je nepopustljiv te je 1762. godine postavio Alfonza za biskupa male i raspršene biskupije Sant'Agata dei Goti, na čijem čelu Alfonz ostaje sve do

\footnotetext{
${ }^{5} \mathrm{O}$ sv. Alfonzu i njegovu kontekstu prema: T. REY-MERMET, Il santo del secolo dei lumi: Alfonso de Liguori, Rim, 1983.; M. COLAVITA, Introduzione, u: Riflessioni utili a' vescovi, 9-55.; J. ANTOLOVIĆ, Duhovni velikani. Sveci Katoličke crkve, II, Zagreb, 1998., 133.

${ }^{6}$ Svoje najpoznatije djelo napisao je 1768. godine, a prevedeno je i na hrvatski jezik: A. LIGUORI, Kako ćemo ljubiti Isusa Krista, Split, ${ }^{4} 2016$. (= Kako ćemo ljubiti Krista).
} 
mirovine. Životopisi sv. Alfonza složni su da je samosvjesno živio kao dobar biskup Kristove Crkve. Bio je jednako uronjen u kontemplaciju koliko u akciju, uvijek ga je krasilo lijepo umijeće propovijedanja i katehiziranja Božjega naroda, osobito u moralnim pitanjima i nauku o duhovnom životu. Bio je neumoran i strpljiv u upravljanju svojom Crkvom, u provođenju dekreta i odredbi Tridentskoga sabora, posebno onih vezanih za odgoj svećenika i vjersku pouku naroda. Rado je okupljao svećenike i za njih pisao priručnike, s gorljivom željom da im i tako pomogne da budu dobri ispovjednici. Pokazao se brižnim za sve ljude i u karitativnom djelovanju tijekom velike gladi koja je 1764. godine pogodila cijelo Napuljsko Kraljevstvo.

Zbog njegova važna doprinosa u obnovi zrelosti vjere, koja je prelazila granice njegove biskupije, Papa mu je na molbu da ga oslobodi službe biskupa i umirovi zbog bolesti odgovorio: »Meni je draže da vi i dalje upravljate biskupijom, pa bilo to i iz kreveta.« U mirovinu odlazi sa 79 godina, nakon 13 godina biskupske službe. Posljednje godine života provodi u samostanu u Noceri dei Pagani, gdje se posvećuje molitvi, studiju, pisanju te duhovnim razgovorima. Umire u 91. godini, 1. kolovoza 1787. godine, na glasu svetosti. Prozvan je najvećom i najimpozantnijom osobom Crkve 18. stoljeća, svecem stoljeća prosvjetiteljstva i Augustinom modernih vremena. Papa Grgur XVI. proglasio ga je svetim 26. svibnja 1839. godine, a spomendan mu je na dan njegove smrti. Papa Pio IX. ubrojio ga je 1871. godine među naučitelje Crkve, a Pio XII. 1950. godine izabrao ga je za nebeskoga zaštitnika ispovjednika i moralnih teologa. ${ }^{7}$

\section{Savjeti biskupima sv. Alfonza Marije Liguorija}

Kako bismo bolje razumjeli kontekst dušobrižništva Alfonzova vremena, ali i to zašto se on odlučio na pisanje uputa biskupima, pokušat ćemo ukratko skicirati crkvene prilike onoga vremena. ${ }^{8}$ Dok u 18. stoljeću Rim broji oko 150000 stanovnika, Napulj ima 442000 stanovnika. U Napuljskom Kraljevstvu živi oko 5 milijuna stanovnika. Prema nekim procjenama 80 -ih godina 18. stoljeća u samom je Napulju bilo oko 3100 svećenika, 3600 redovnika i 6400 redovnica, a ukupno u Napuljskom Kraljevstvu bilo je 120 000, što svećenika, što redovnika i redovnica, što je činilo skoro $4 \%$ tadašnje populacije Kraljevstva. U istom Kraljevstvu u 18.

\footnotetext{
${ }^{7}$ O važnosti sv. Alfonza za moralnu teologiju vidi više u: M. SRAKIĆ, Moja je savjest čista. Teološki radovi o moralnom životu i nasljedovanju Krista, odgoju savjesti i božanskim krepostima, Sabrana djela, II, Đakovo, 2013., 77-78., 95., 160-161., 187., 236., 238-246., 278., 363. »U XVII. i XVIII. st. povijest moralne teologije svodi se na jednostavnu shemu: borbu između laksista i rigorista, između probabilista i probabiliorista.« Isto, 77. Sv. Alfonz izradio je svoj sustav - ekviprobabilizam. Usp. isto, 78., 242.

${ }^{8}$ Prema: M. COLAVITA, Introduzione, 31-37.; T. REY-MERMET, Il santo del secolo dei lumi: Alfonso de Liguori, 487-488., 627.
} 
stoljeću bilo je oko 150 (nad)biskupa, odnosno 131 biskupija, među kojima 21 nadbiskupija. Za razliku od nekih drugih područja biskupi Napuljskoga Kraljevstva nerijetko su živjeli mnogo skromnije u svojim malim biskupijama.

Dosta biskupa živjelo je u samom Napulju, tj. izvan svojih biskupija. I sam nasljednik sv. Alfonza, mons. Onofrio Rossi, tijekom petogodišnje službe u središtu biskupije rezidirao je svega nekoliko sati. Izbor novih biskupa znao je biti vođen rodbinskim vezama, što je dovodilo do niske razine moralnoga i duhovnoga života biskupa. Konkretno gledano, biskupska služba ostvarivala se ponajviše na birokratski način. Biskup je bio taj koji mora provoditi dekrete, norme i odredbe Tridentskoga koncila. Biskup je svoje snage često trošio na borbu protiv raznih crkvenih struja kako bi obranio svoje stavove ili interese, na štetu brige za dobro duša. Napuljsko Kraljevstvo imalo je oko 3700 župa, što je mali broj u odnosu na broj biskupija. Bile su i loše raspoređene te pod utjecajima velikoga broja samostana, svetišta i bratovština. Svećenici su često ulazili u polemike s biskupima, bilo zbog ljubomore bilo zbog željene veće autonomije, te su bili privrženi civilnim vlastima kako bi si osigurali zaštitu. Sve je to dovelo do ozbiljnoga stanjivanja biskupske službe, dekadencije svećenstva i redovništva te do malaksalosti i konfuzije u životu vjere općenito. Dakako, ni u 18. stoljeću nije manjkalo biskupa koji su bili istinski duhovni pastiri posvećeni brigama za duše, ali su očito tendencije bile drukčije. U tekstu koji je pripremio za izbor nasljednika pape Klementa XIV. (1769. - 1774.) umirovljeni i blagi biskup Alfonz konstatira da ima dosta biskupa koje treba kazniti suspenzijom ili na njihovo mjesto poslati apostolske vikare kako bi popravili štetu koja je nastala.

Temeljno djelo kojim sv. Alfonz nastoji obnoviti istinsku narav biskupskoga reda nastalo je 1745. godine kao jedan od plodova Alfonzovih iskustava u pučkim misijama, gdje je imao priliku steći ispravnu dijagnozu stanja i konkretnih problema u Crkvi. Prvi korak popravka, odnosno obnove Crkve sv. Alfonz vidi upravo u obnovi istinske naravi biskupske službe, odnosno u obnovi biskupske gorljivosti za duše preko podsjećanja na dužnosti koje treba ispuniti svaki biskup. Za sv. Alfonza biskupska služba nije privilegiji ili odskočna daska u crkvenoj karijeri, nego posve suprotno - to je služba teške, tvrde i ozbiljne odgovornosti, jedinstvene u Crkvi.

Sv. Alfonz odgovornost biskupske službe tumači na sljedeći način. Polazi od Pavlovih riječi starješinama u Efezu: »Pazite na sebe i na sve stado u kojem vas Duh Sveti postavi nadglednicima, da pasete Crkvu Božju.« (Dj 20, 28) Kao potvrdu toga navodi nekoliko vrlo važnih misli preuzetih od sv. Karla Boromejskoga, sv. Atanazija i sv. Grgura. Prvo, za grješan život stada krivnju snose pastiri. Drugo, biskup poslije ređenja ne može više živjeti samo za sebe, nego isključivo za svoje stado. I treće, dok će nam svima pred Kristovim sudištem suditi za naše živote, jedino će biskupima suditi i za svaku dušu koja je pripadala njihovim Crkvama. Tako se može dogoditi 
da pojedini biskup koji je osobno živio svetim životom na Kristovom sudištu bude prepoznat kao nedostojan jer nije mario za spasenje svoga stada i zato snosi golemu odgovornost za sve grijehe toga stada.

Za sv. Alfonza posve je dakle jasno da svetost Božjega naroda prvo i najviše ovisi o biskupima kao upraviteljima svojih Crkava. Ili, drukčije rečeno, za sv. Alfonza posve je očito da, iako je broj biskupa i svećenika jako velik, velika je i neodgovornost pastira spram spasenja stada. Zato, poput pravoga duhovnoga arhitekta, u svojim uputama sv. Alfonz pozorno izrađuje nacrt za doista moguću obnovu biskupske službe u Crkvi.

Iako su već postojala slična djela (npr. Regula pastoralis sv. Grgura Velikoga, Dobar biskup Giuseppea Crispina i dr.), sv. Alfonz primijetio je da ona ipak nisu čitana i promišljana. Ponajviše zato što su velika i prezahtjevna, a kao takva traže dosta vremena, što opet znači manje vremena za brigu za duše. Kako njegovo djelo ne bi doživjelo istu sudbinu, Alfonz se trudi biskupima napisati što kraći i što jasniji vademecum u koji će sažeti sve ono najbitnije za ispravnu i plodnu orijentaciju u obavljanju njihove službe upravljanja Božjim narodom. Podijelio ga je na dva dijela: prvo piše o šest najvažnijih briga svakoga biskupa, a potom o devet najučinkovitijih biskupovih sredstava za upravljanje svojom Crkvom. Tu ćemo podjelu i mi slijediti u daljnjoj analizi. ${ }^{9}$

\subsection{NAJVAŽNIJE BRIGE SVAKOGA BISKUPA}

Redoslijed nikad nije nevažan. Stoga je sv. Alfonz na prvo mjesto temeljnih briga svakoga biskupa stavio sjemenište, i to zato što je njegova zadaća odgojiti i formirati dobar i svet kler, o kojem ovisi svetost i duhovna zrelost Božjega naroda. »Zato ako za sjemeništa nema dostatnih prihoda, kako za ishranu mladih (bez koje ih se ne može držati disciplinirane), kako za uzdržavanje dobrih službenika i odgojitelja, bolje je da sjemeništa ni ne postoje $\ll .{ }^{10}$ Međutim nije to jedina biskupova briga za tu ustanovu. Ako sjemenište nije pravilno organizirano, ono će postati propast, a ne posvećenje biskupije. U sjemeništu, prema našem svecu, mladi trebaju primiti novi, sveti duh, koji će ih osloboditi od svih nedostataka i poroka koje sa sobom unose u sjemenište. Međutim sv. Alfonz primjećuje: $\gg$ Koliki u sjemenište ulaze kao anđeli i ubrzo postaju demoni! « te nastavlja: »Treba biti uvjeren da je, generalno govoreći, u sjemeništima puno više zala i skandala nego što to biskupi znaju. ${ }^{11}$ Zato naš svetac daje upute kako će sjemenište postati mjesto posvećenja jedne biskupije. Kao

\footnotetext{
${ }^{9}$ Temeljni tekst našega prikaza jest: Riflessioni utili a' vescovi, 57-96.

${ }^{10}$ Isto, 60 .

${ }^{11}$ Isto.
} 
prvo, biskup u sjemenište treba postaviti dobroga rektora, koji se odlikuje gorljivošću za Boga, snažnim duhovnim iskustvom te oštroumnošću, kako bi mogao uočiti sve probleme i kako ga se ne bi moglo prevariti. On treba uvijek biti u sjemeništu, čak treba i objedovati s pitomcima. Nije lako, kaže sv. Alfonz, naći takva svećenika, ali je to nužna biskupova zadaća.

U sjemeništima valja osigurati dovoljan broj prefekata. To, prema sv. Alfonzu, trebaju biti zreliji, stariji svećenici, duhovni i jaki u ispravljanju mana i propusta. Osobito trebaju paziti da se pitomci ne rugaju jedni drugima i da vrijeme ne provode $\mathrm{u}$ ispraznim pričama. Tamo gdje sami ne uspijevaju popraviti stanje imaju obvezu zatražiti rektorovu pomoć, a po potrebi i biskupovu. Zanimljivo je primijetiti da sv. Alfonz, u želji da poglavari sjemeništa doista imaju pravu sliku stanja, preporučuje odabiranje dvaju ili triju izviđača za svaku spavaonicu, biranih iz redova najduhovnijih i odanih pitomaca, koji će jednom tjedno tajno izvještavati rektora i biskupa o stvarnom stanju u sjemeništu. To je posve u skladu s onim što na drugom mjestu naučava sv. Alfonz, a tiče se preporučljivoga, štoviše, nužnoga nepovjerenja koje trebaju imati svi oni kojima je povjereno upravljanje drugima. ${ }^{12}$ Vidjet ćemo kasnije da će se na to nepovjerenje sv. Alfonz često vraćati kako bi spriječio velika zla koja mogu nastati nesmotrenim biskupovim povjerenjem.

Nadalje je vrlo važno da biskup posjećuje sjemenište, da bude nazočan na događanjima u njemu i uvijek potiče sjemeništarce na duhovni rast. Najmanje dva ili tri puta godišnje biskup treba obaviti skrutinije za svakoga pojedinoga pitomca kako bi se osobno uvjerio jesu li onakvi za kakve se drže. Dakako, one nepopravljive i one koji izazivaju sablazan valja odmah otpustiti jer je dovoljan samo jedan takav da pokvari cijelu zajednicu. Biskup treba bdjeti nad duhovnim stvarima u sjemeništu, određujući zajedničke meditacije ujutro i uvečer. Sadržaji tih meditacija trebaju biti vječne istine, koje su korisne u udaljavanju od mladenačkih poroka. ${ }^{13} \mathrm{Jednom}$ godišnje sjemeništarci moraju obaviti duhovne vježbe u trajanju od osam dana, u potpunom miru, tišini i samoći. Neka se biskup pobrine da barem jednom mjesečno sjemeništarci čuju propovijed svećenika s bogatim dušobrižničkim iskustvom. Biskup treba paziti da se sjemeništarci redovito ispovijedaju. Sv. Alfonz savjetuje da to bude svakih 8 ili 15 dana. Za to treba osigurati najbolje svećenike, najmanje dvojicu, pazeći da se pitomci ne ispovijedaju samo kod onih svećenika koje osobno poznaju jer to može biti povod za slab duhovni rast. Naš svetac daje uputu biskupima da paze i na to što bogoslovi čitaju. Neka im zato posebno preporučuje životopise

${ }^{12}$ Usp. A. LIGUORI, Vježbanje u savršenosti, Split, 2014., 71. (= Vježbanje u savršenosti).

${ }^{13}$ Sažetak vječnih istina, ili općih načela vječnoga života, sv. Alfonz donosi u: Kako ćemo ljubiti Isusa Krista, 195. 
svetaca, druga teološka i filozofska djela, latinski jezik te osobito moralnu teologiju kako bi mogli biti dobri ispovjednici.

Drugo posebno područje biskupove brige jesu ređenici, odnosno oni koji su neposredni kandidati za prezbiterat. Za našega sveca tri su znaka kojima se prepoznaje pravo svećeničko zvanje: »usvojen ispravan nauk, odluka da će se služiti jedino Bogu te dobro ponašanje i uzoran život. $\ll{ }^{14}$ Dok biskup nema toga uvjerenja, bez obzira na preporuke, časti, talente i znanje pojedinoga, ne treba ga pripustiti ređenju jer Crkvi ne trebaju mnogi svećenici, nego dobri, sveti svećenici. Također ne treba zarediti one koji nisu bili najmanje tri godine u sjemeništu. Biskup treba ispitati duh i znanje kandidata za ređenje. Pritom se ne smije zadovoljiti pisanim preporukama župnika, jer su one često pisane s odviše obzira prema kandidatu i njegovoj obitelji, ni samo time da je kandidat jednostavno dobar čovjek. Biskup mora imati informacije koje će ga dovesti do uvjerenja da je u kandidatu za ređenje istinski crkveni duh. Zato je potrebno prikupiti što više mišljenja, napose od onih osoba koje poznaju kandidata. Taj korak nužnoga nepovjerenja u prvom je redu usmjeren tomu da biskup sazna što više o duhovnom životu kandidata za prezbiterat (posjećuje li crkve kad nije u sjemeništu, moli li, živi li uzorno, kreće li se u dobrom društvu, posvećuje li se osobnom studiju, oblači li se dolično...).

Ako su sva mišljenja i pozitivna, s ređenjem opet ne valja žuriti jer nitko ne smije biti zaređen ako prije nije dostatno prokušan. Na jednom će drugom mjestu sv. Alfonz zapisati vrlo važnu misao: »U slučaju, dakle, kad ređenik ne živi prokušano valjanim životom, ne griješi samo on, koji se zaređuje, nego griješi i biskup koji mu bez propisane kušnje podjeljuje sveti red i time je moralno odgovoran za dobar život ređenika. $\ll{ }^{15}$ Biskup zato treba biti što sigurniji da je cjelokupan kandidatov život prikladan za ređenje. Tomu bi trebala pridonijeti i ustanova svojevrsnih instituta diljem biskupije, gdje bi kandidati prije ređenja odlazili svakoga tjedna kako bi se pod duhovnim vodstvom svećenika, a ponekad i u biskupovoj nazočnosti, vježbali u krjeposti, razmatranju, plodnom primanju sakramenata, klanjanju te pobožnosti prema Djevici Mariji. ${ }^{16}$ Mišljenje svećenika voditelja svakako treba uzeti u obzir pri donošenju suda o prikladnosti kandidata za ređenje.

U tom kontekstu sv. Alfonz spominje i biskupovu brigu o znanju onih koje će zarediti: »Sigurno je«, piše naš svetac, »da neznanje svećenika čini veliku štetu kako

\footnotetext{
${ }^{14}$ Isto, 112.-113.

${ }^{15}$ Isto, 114. Kurziv je naš.

${ }^{16}$ Sv. Alfonz njegovao je intenzivan duhovni odnos prema Presvetoj Djevici, ponajviše željom za čašćenjem i nasljedovanjem Otkupiteljeve majke. Napisao je djelo Le glorie di Maria koje i danas nadahnjuje vjerničku marijansku pobožnost. U hrv. prijevodu: A. M. DE LIGUORI, Zdravo Kraljice, I-II, Zagreb, 2004.
} 
njima samima, tako i drugima. Najgore je što je neznanje svećenika zlo bez lijeka, kako je govorio sv. Franjo Saleški. $\ll{ }^{17}$ Biskup mora bdjeti nad posvećenosti kandidata za svećeništvo studiju. Ne samo zato što bez solidnoga znanja ne će biti dobri za Crkvu nego i zato što će nužno biti loši, grješni, jer je lijenost izvor mnogih grijeha. Zato biskup mora steći uvjerenje da je kandidat zaista privržen studiju, naporu stalnoga promišljanja i ne smije se zadovoljiti nekim jednostavnim ispitom kojim će provjeriti tek činjenično znanje. Mnogi biskupijski svećenici, ako ne i svi, kaže sv. Alfonz, nakon ređenja nisu otvorili ni jednu knjigu. Tomu je tako jer za vrijeme priprave na svećeništvo nisu stekli naviku studiranja i ljubav spram teologije.

Svećenici su treća skupina prema kojoj biskup treba iskazivati veliku brigu. Dobri svećenici biskupove su ruke bez kojih nema plodnosti u biskupiji. Zato je vrlo prikladno da biskup zna pokazati svoju naklonost prema dobrim svećenicima, onima koji istinski dobro rade, nagrađujući ih po zaslugama. Dijeliti te nagrade ne po stvarnim zaslugama, nego po svjetovnim ili privatnim mjerilima za sv. Alfonza jest >opći izvor svih nereda u Crkvi Božjoj $\ll .{ }^{18} \mathrm{~S}$ druge strane biskup mora pokazati svoje nezadovoljstvo pred nemarnim svećenicima kako bi ih tako pokušao popraviti. Naš svetac poziva biskupe da vode brigu o prikladnom izgledu i odijevanju svojih svećenika, upozoravajući da neki svećenici odviše drže do svoga izgleda, što može sablazniti jednostavni svijet.

U tom kontekstu sv. Alfonz posebnu pozornost poklanja svećeničkoj službi ispovijedanja. Ispovijedanje je teška služba s velikim posljedicama, zato biskup treba uložiti sve napore da se budući ispovjednici dobro priprave. Kaže naš svetac: »Ispovjednici bez znanja ili oni s lošim vladanjem mogu uništiti sve druge; zbog toga je bolje imati manje ispovjednika, ali dobrih. ${ }^{19}$ Jedna od najvažnijih biskupovih briga, ako ne i najvažnija, upravo je briga za dobre ispovjednike, o kojima ovise savjesti svih članova Božjega naroda. Kao znak takve brige za svećenika sv. Alfonz preporučuje ustanove moralnih akademija ili instituta te uvođenje obveze svećenicima, osobito mlađima, da ju pohađaju dva ili tri puta tjedno kako bi se usavršavali $\mathrm{u}$ moralnoj teologiji, posebno u ispovijedanju. $\mathrm{U}$ toj bi akademiji ponavljali gradivo, proširivali svoje znanje te rješavali kazuse. Akademijom bi upravljao prokušani svećenik, uz povremenu biskupovu nazočnost, a nitko ne bi mogao dobiti ovlast za ispovijedanje bez najmanje dvogodišnjega sudjelovanja na takvim konferencijama i obavljenih duhovnih vježbi.

\footnotetext{
${ }^{17}$ Riflessioni utili a' vescovi, 64-65.

${ }^{18}$ Isto, 66.

${ }^{19}$ Isto, 67.
} 
Sljedeća, četvrta skupina temeljne biskupove brige i pozornosti jesu župnici. Nakon opće upute biskupima da paze da župnici svake godine obave duhovne vježbe, kako bi mogli rasti u duhovnosti i revnosti za duše, sv. Alfonz prelazi na upozorenje kako je jako malo onih župnika koji mogu obavljati tešku i važnu župničku službu, o kojoj ovisi spas ili propast naroda. Zato prije nego ih postavi, biskup se mora dobro informirati o njihovoj doraslosti u duhu i znanju za tu službu. Isto tako biskup mora biti marljiv u uvjeravanju župnika u važnost ispravnoga obavljanja njihove službe, osobito ih potičući na obiteljski intonirane, pripravljene i motivirajuće homilije o vječnim istinama te na pohode umirućima i stalnu spremnost na ispovijedanje onoga koji to zatraži. Bezvoljnost i ravnodušnost župnika spram rečenoga često je izvor teških skandala u očima Božjega naroda. Uz propovijedanje i ispovijed temeljno je poslanje župnika borba protiv grijeha u njihovim župama. Na to ih biskup treba podsjećati te ih uvijek treba biti spreman primiti kako bi im pomogao u tome poslanju. Za sv. Alfonza jako je važno da župnici imaju svijest da će ih biskup uvijek primiti kako njihova briga za duše ne bi imala ispriku. Zato naš svetac savjetuje da o tome prioritetu župnika na prijem jasno budu upoznati svi koji djeluju uz biskupa ili mu služe.

Biskup također mora bdjeti nad župnicima i pod vidom dijeljenja sakramenata kako nitko ne bi ostao neopravdano uskraćen za sakramente. Zbog potreba duša sv. Alfonz predlaže biskupima održavanje svojevrsne skupštine na kojoj bi se župnici najmanje jednom mjesečno zajedno $s$ biskupom i njegovim savjetnicima hvatali u koštac sa svim problematičnim situacijama i potrebama župničke službe, osobito pastoralnoga, duhovnoga, moralnoga i pravnoga područja, te zajednički iznalazili rješenja. »Na ovim skupštinama biskup treba dati svakome punu slobodu upozoravanja i govora o svemu što je potrebno za slavu Božju. (...) Ako bi svaki biskup ovako činio, kolike bi se stvari bolje primijetile i od kolikog bi se zla očuvalo, koje se inače ne da primijetiti ni popraviti. $\ll^{20}$

Slijedi peta među najvažnijim biskupovim brigama, a posvećena je njegovu vikaru $i$ najbližim suradnicima. »U izboru najbližih suradnika prva biskupova odluka, kako bi dobro upravljao svojom biskupijom, treba biti da nikako ne izabire suradnike po rodbinskoj, prijateljskoj ili bilo kojoj drugoj svjetovnoj liniji. ${ }^{21}$ To na poseban način vrijedi za službu biskupova, današnjim rječnikom rečeno, generalnoga vikara, o kojem uvelike ovisi mir i red u biskupiji. Biskup mora izabrati vikara vrlo pomno, pazeći da ga rese duh i znanje, blagost i ljubaznost, spremnost da uvijek primi one koji to zatraže, da se svojom službom ne koristi za osobne interese te da mu mito bude potpuno strano, ali i da nerado prima bilo kakve darove. Bilo bi dobro da se

\footnotetext{
${ }^{20}$ Isto, 71 .

${ }^{21}$ Isto.
} 
biskup i vikar susreću svakoga dana kako bi se biskup na vrijeme upoznao s problemima, slučajevima i poslovima za koje mora donijeti odluke.

Biskupski dvor treba odisati pobožnošću. Zato iz njega treba udaljiti sve one koji žive daleko od Boga. U protivnom će biskup zasluženo naići na negodovanje Božjega naroda. Osobito neka pazi da nitko od njegovih najbližih suradnika ne bude sklon podmićivanju bilo koje vrste jer će sve to sigurno jednom naškoditi biskupovu dobrom glasu i njegovoj službi. Neka zato ni biskup ne prima darove, osobito ne od svojih svećenika, kandidata za ređenje i redovnica, osim baš onih uobičajenih.

Zadnja najvažnija biskupova briga jesu ženski samostani. Sv. Alfonz kaže da su »posvećene djevice najsjajniji dio stada Isusu Krista ${ }^{22}$ Biskup treba voditi brigu da redovnice zaista žive kao redovnice. Zato neka nitko ne obuče redovnički habit, a da sam biskup nije uvjeren da je riječ o istinskom redovničkom zvanju. Valja uvijek biti svjestan da se mnoge žene ne odlučuju za samostane zbog zvanja i potpunoga posvećenja Bogu, nego zbog roditelja ili drugih krivih razloga. ${ }^{23}$ Zato se u mnogim samostanima ne osjeća pravi duh, nego raspuštenost. Sv. Alfonz poziva biskupe da paze da svaki samostan ima oblikovan zajednički život, da oni vode brigu tko može doći u samostan razgovarati s redovnicama te da spriječe svaki oblik financijskih abuzusa, kojima su redovnice sklone (nepotrebna slavlja, darovi svećenicima ...). Isto tako biskup neka pazi da poglavarice uistinu budu one koje krasi duhovnost, mudrost i razboritost jer najviše o njima i o ispovjednicima ovisi hoće li u samostanu biti red ili nered. »Treba znati da kad jednom neki abuzus ude u samostan, gotovo ga je nemoguće iz njega odstraniti. Za sve abuzuse poglavarice i ispovjednici snose krivicu. $\ll^{24}$ Zato biskup treba paziti komu i na koliko dugo povjerava osjetljivu službu redovitoga ispovjednika u ženskim samostanima te treba nekoliko puta godišnje slati izvanredne ispovjednike kako bi se ispravile moguće loše ispovijedi s redovnim ispovjednicima. Dobro je da redovnice svake godine obave duhovne vježbe pod vodstvom svećenika koji se odlikuje svjedočanstvom vlastita života, mudrošću i duhom zajedništva. Ako nema takvih, bolje je da redovnice same za sebe obave duhovne vježbe jer su mnogi svećenici svojim lošim propovijedima raspustili, ako ne i posve uništili, pojedine samostane. Time sv. Alfonz zaključuje govor o najvažnijim biskupovim brigama i prelazi na drugi dio svojih uputa.

\footnotetext{
${ }^{22}$ Isto, 72 .

${ }^{23}$ Obitelj i rodbina mogu biti, prema sv. Alfonzu, najveći neprijatelji djetetove duše, osobito pod dvama vidovima - bilo da guše (svećeničko i redovničko) zvanje bilo da ga nameću. Zato se, općenito, treba odijeliti od neuredne ljubavi prema rodbini. »Isus Krist nije ustanovio svećenički stalež kao potporu obiteljima iz kojih potječu svećenici, nego radi slave Božje i spasenje duša.« Kako ćemo ljubiti Isusa Krista, 114. Usp. isto, 110-112.; Vježbanje u savršenosti, 92s.

${ }^{24}$ Riflessioni utili a' vescovi, 74.
} 


\subsection{NAJUČINKOVITIJA BISKUPOVA SREDSTVA ZA DOBRO UPRAVLJANJE SVOJOM CRKVOM}

$\gg$ Treba da nadglednik bude besprijekoran «, riječi su Prve poslanice Timoteju (3, 2) kojima sv. Alfonz započinje drugi dio svojih uputa posvećen najučinkovitijim biskupovim sredstvima za dobro upravljanje svojom Crkvom, koji biskupa trajno posvećuju i potvrđuju kao besprijekorna nadglednika. »Drvo koje ne izgara ne može zapaliti druga drva $\ll,{ }^{25}$ piše naš svetac. Zato biskup jednostavno mora biti besprijekoran. O tome ovisi može li uistinu posvećivati svoje stado: »Pripazi na samog sebe i na poučavanje! Ustraj u tome! Jer to vršeći, spasit ćeš i sebe i one koji te slušaju « $(1 \operatorname{Tim} 4,16)$

Na prvo mjesto spomenutih sredstava za rast u biskupovoj osobnoj besprijekornosti i dobrom upravljanju sv. Alfonz stavlja molitvu. Bez molitve, po kojoj se prima svjetlo, snaga i žar, nema svetosti jer je molitva »najpotrebnije sredstvo za duhovni život i za stjecanje ljubavi Božje $\ll{ }^{26}$ Biskupova molitva mora biti svakodnevna, pa ako treba i noćna molitva, a osobito treba prakticirati misaonu molitvu ili razmatranje. Na toj formi molitve kao na važnom sredstvu za osobno posvećenje i izbjegavanje mlakosti sv. Alfonz inzistira skoro u svim svojim djelima. ${ }^{27}$ Tako piše: »Mnoga su dobra što ih primamo u razmatranju: bude se svete misli, vježbaju se pobožna čuvstva, pobuđuju svete želje i stvaraju čvrste odluke da ćemo se posve predati Bogu. Na taj način zbog Boga se odričemo svih zemaljskih užitaka i svih neurednih osjećaja i navezanosti. (... ) Tko ne razmatra, ne može znati što uistinu treba njegovoj duši; ne primjećuje napasti koje mu idu u susret; ne poznaje sredstva kojima se mora poslužiti da ih nadvlada. I tako, slabo poznajući potrebu misaone molitve, propustit će je i sigurno će se izgubiti. ${ }^{28}$ Iako $\gg$ osoba molitve mora ljubiti samoću i ne smije se rastresati suvišnim poslovima koji na nju ne spadaju, inače će izgubiti duh sabranosti koji je veliko sredstvo u podržavanju jedinstva s Bogom $\ll_{,}{ }^{29}$ dobro je da se biskupa katkada javno vidi kako osobno moli.

Opisujući biskupsku službu Kristovim riječima o svijećnjaku koji svijetli svima u kući (usp. Mt 5, 15), drugo temeljno biskupovo sredstvo upravljanja sv. Alfonz vidi u osobnom dobrom primjeru. Kako smo već vidjeli, nije dovoljno da biskup u sebi bude dobra i sveta osoba, nego se ta dobrota i svetost trebaju utjeloviti u njegovoj

\footnotetext{
${ }^{25}$ Isto, 76.

${ }^{26}$ Kako ćemo ljubiti Isusa Krista, 85.

${ }^{27} \mathrm{O}$ metodi misaone molitve sv. Alfonza, koja se sastoji od priprave, promatranja i zaključka, vidi više u: Vježbanje u savršenosti, 184-186.

${ }^{28}$ Kako ćemo ljubiti Isusa Krista, 78., 80.

${ }^{29}$ Isto, 79.
} 
službi, a to znači u njegovu poslanju i svim relacijama koje iz njega nužno izviru. Biskup mora biti uvijek svjestan činjenice da njegovi svećenici i vjernici vjeruju više očima, dakle onomu što vide, nego ušima, odnosno onomu što čuju. Zato naš svetac poziva biskupe biblijskim riječima: »U svemu se pokaži uzorom dobrih djela.« (Tit 2,7) Kako to 'u svemu' ne bi ostalo apstraktno, sv. Alfonz posebno izdvaja dvoje: blagost, osobito spram neuljudnih svećenika i vjernika, koja podrazumijeva spremnost da se na zlo i nezahvalnost uzvrati dobrim; i siromaštvo, odnosno istinsku nenavezanost, ${ }^{30}$ jer milostinja kojom biskup upravlja treba služiti za pomoć potrebnima, te je zato bolje biti u dugu zbog pomaganja siromasima, nego nagomilavati milostinju ili ju trošiti na osobne užitke. Dakako, biskup treba imati za pristojan život kako bi mogao obavljati svoju službu, ali u tome treba paziti da umjereno ima ono što je nužno za takav život, bez nepotrebnoga uresa i sjaja. Luksuz i obilje ne smiju biti oznake ni biskupovih stanova ni njegove odjeće i hrane. Spomenimo ovdje i to da sv. Alfonz potiče biskupe da im objedi sa svećenicima i vjernicima uvijek budu prigode za prikladne kratke duhovne nagovore, po uzoru na sv. Karla Boromejskoga.

Sljedeće je sredstvo obveza rezidiranja. Biskupi stalno nose svoj prsten kako bi uvijek gajili samosvijest da više nisu svoji, nego da pripadaju svojoj Crkvi, svojoj zaručnici. Konkretna forma toga pripadanja jest biskupova obveza sjedišta, odnosno stabilne nazočnosti u središtu svoje Crkve prema odredbama Tridentskoga koncila. Kad biskup opravdano mora iz njega izbivati, treba, prema sv. Alfonzu, željeti što prije u njega se vratiti.

Potom naš svetac prelazi na sredstvo kojemu posvećuje najveći broj svojih redaka. Riječ je o vizitacijama pojedinih mjesta vlastite biskupije. Piše sv. Alfonz: »Onaj tko ne vidi, ne može poduzeti potrebno. $\ll^{31}$ Nemoguće je dobro upravljati biskupijom samo preko drugih jer drugi znaju prevariti zbog vlastitih interesa ili se daju lako obmanuti ili jednostavno ne uoče ono što valja uočiti. To je sv. Alfonz posebno dobro iskusio tijekom održavanja pučkih misija, te zato i ovdje biskupe potiče na određeno nepovjerenje prema onomu što drugi govore. Tridentski koncil odredio je da biskup mora barem svake dvije godine vizitirati župe svoje biskupije, a prema našemu svecu ne postoji nikakav valjan izgovor da se to i ne obavi. Zatim razvija hodogram vizitacije župe ili određene regije:

- Biskup u vizitaciji neka prije svega pase svoje stado Božjom riječju i svojim glasom. Prema tomu propovijedanje je najvažniji dio vizitacije, a u njemu biskup treba progovoriti o vječnim istinama, koje su najjače oružje za dobrobit duša, te

\footnotetext{
${ }^{30}$ Usp. Kako ćemo ljubiti Isusa Krista, 103s.; Vježbanje u savršenosti, 80s.

${ }^{31}$ Riflessioni utili a' vescovi, 90.
} 
protiv grijeha općenito, ali posebno o onima koji su tipični za župu koju vizitira te na kraju potaknuti na primanje sakramenata te na trajno utjecanje Isusu Kristu i Presvetoj Djevici.

- Dobro je da biskup u susretima provjeri kako su djeca poučena u vjeri, provjeravajući tako i župnikovu marljivost u poučavanju. Ako je znanje slabo, treba svakako ukoriti župnika zbog nemara i pobrinuti se da se djeca dostatno i prikladno pouče.

- Osobito u selima biskup treba ispitati poznaju li svećenici sve liturgijske odredbe o slavlju mise.

- Biskup se treba susresti osobno sa svakim svećenikom i bogoslovom koji živi na području koje vizitira. $U$ tome povjerljivom razgovoru treba porazgovarati o vlastitim službama i životu pojedinoga svećenika te ga potaknuti, prema potrebi, na revnije ispovijedanje ili odlazak umirućima ili pak na bolje posvećenje studiju i molitvi te otklonu od loših razgovora. Prilika je to da se biskup raspita i o drugim svećenicima, osobito o župniku, jer je prvi cilj (ondašnjih) vizitacija obnova same župničke službe. Potom se treba raspitati o grijesima i problemima kraja. U takvim pojedinačnim i povjerljivim susretima biskup može mnogo toga otkriti što bi se inače teško saznalo i povezalo, a time ostalo nepopravljeno. Korisno je, i kasnije se može upotrijebiti u mnogo dobrih svrha, da biskup vodi bilješke o onome što čuje.

- Ako postoje ženski samostani, pri vizitaciji biskup ih svakako treba pohoditi, održati im propovijed te se susresti sa svakom redovnicom kako bi čuo potrebe i stekao uvid u stanje života u samostanu te dao upute kako bi se u njemu bolje i svetije živjelo. Pomno se treba čuvati utjecaja različitih struja na koje može naići u samostanima.

- Svakako neka obrati pozornost na tišinu u crkvama te na prikladno uređenje crkve i dolično stanje liturgijskoga ruha. Ako treba, neka ostavi pisane upute kako otkloniti uočene nedostatke.

- Svakako bi bilo dobro da se pri vizitaciji biskup posveti i laičkim kongregacijama, odnosno, današnjim rječnikom, župnim skupinama odraslih vjernika. Kaže sv. Alfonz da ako laici ne sudjeluju u takvim skupinama, teško da će sudjelovati u sakramentima i očuvati se u milosti Božjoj. Neka biskup provjeri imaju li takve skupine duhovno vodstvo, a tamo gdje nema tih skupina neka potakne njihovo osnivanje. Neka otkloni mogućnost bilo kakvih financijskih malverzacija u takvim skupinama te sve pozove na redovitost.

- Vizitacije su prilika i za podjelu sakramenta krizme te sakramenta pokore. U ispovjedaonici biskup može primiti i osobe koje s njim žele razgovarati privatno. 
Iako su u ono vrijeme neki tu mogućnost vidjeli kao priliku za obmanu biskupa, sv. Alfonz ipak drži da je ta mogućnost dobra kako bi biskup što bolje upoznao pravo stanje župe koju vizitira, svakako razlučujući duhove, čuvajući se spletkarenja i uplitanja u ogovaranje.

Tako smo došli do petoga sredstva, a to su pučke misije. Iz svoga bogatoga iskustva sv. Alfonz moli biskupe da se pobrinu da svako mjesto njihovih biskupija bude blagoslovljeno održavanjem misija. Glavni je cilj tih misija plodno obavljanje sakramenta pokore. Nakon intenzivnoga vremena navještaja Riječi Božje i vječnih istina jako je važno da se vjernici ispovjede i to baš kod misionara kako bi se posve oslobodili grijeha kojih se stide ili ne žele priznati pred svojim svećenicima. Neki župnici govore da misije nisu poželjne jer uznemiruju vjernike. Sv. Alfonz upravo u tom uznemiravanju vidi smisao misija, ako je to uznemiravanje zbog osobne grješnosti i poziv na stvarnu promjenu života, na obraćenje. Kaže da »to upravo treba biti pastirova briga, dati da se uznemire ovce koje spavaju u grijehu, kako bi se probudile, spoznale opasnost u kojoj žive i tako se vratile Bogu; za ovo ne postoji bolje sredstvo od misija «. ${ }^{32}$ Zato je važno da misije budu temeljito obavljene, da traju barem osam dana (sv. Alfonz piše i o misijama koje traju 10, 20, pa čak i 30 dana) kako nitko ne bi imao ispriku da nije znao ili stigao. Neka se upriliče svake tri godine kako bi se obraćeni utvrdili, a grješnici pozvali na obraćenje. Biskup neka pazi da u svakoj župi, pa i najmanjoj, bude misija i da se ne dogodi da misije uvijek budu samo u istim mjestima.

Šesto sredstvo za dobro upravljanje i obnovu Crkve jest sinoda. To »iznašašće Duha Svetoga $\ll,{ }^{33}$ kako ju naziva sv. Alfonz, prilika je da se na sjednicama razmotre svi problemi koji pritišću biskupiju i župe te župnicima daju teološke, moralne, pastoralne, liturgijske i sve druge potrebne upute, od uređenja crkve do borbe protiv grijeha (npr. sv. Alfonz navodi grijeh psovke). Pri raspravama neka biskup bude radije suzdržan i oprezan nego da prelazi te granice gušeći sinodalnost.

Savjetovanje je sljedeće, sedmo biskupovo sredstvo za vođenje biskupije, kojim pokazuje da nije navezan samo na svoje mišljenje. Prvo što bi, prema sv. Alfonzu, novi biskup trebao učiniti jest proći biskupijom i dobro uočiti sve njezine probleme te promisliti kako ih riješiti. Neka mu u tome glavni savjetnik bude Bog, kojemu će se svakodnevno obraćati u svojoj molitvi. Budući da Sveto pismo uči da »mudar čovjek sluša savjete « (Izr 12, 15), neka biskup čuje mišljenja i svojih savjetnika. Njih treba izabrati iz reda onih koji se odlikuju znanjem, razboritošću i strahopoštovanjem kako bi preko takvih sigurnije mogao saznati što Bog hoće od njega. Po-

\footnotetext{
${ }^{32}$ Isto, 86.

${ }^{33}$ Isto, 89.
} 
tom neka donese odluke. No najvažnije je da on sam čvrsto stane iza provedbe tih odluka, odnosno da podrži one koji ih prihvaćaju, a ne podrži one koji ih odbijaju. To je vrlo važno jer, kaže sv. Alfonz, »u protivnom je bolje ne donositi ih; budući da ako se vidi kako biskup podržava nepoštivanje odluka bez posljedica, dogodit će se da će se omalovažiti sve druge njegove odluke. (...) Nikad neće biti dobar biskup koji se u Božjim interesima boji neugodnosti od ljudi. $\ll^{34}$

Pretposljednje temeljno biskupovo sredstvo jest privatna audijencija. »Izuzev vremena za molitvu, misu i nužni odmor, biskup mora biti spreman primiti sve u bilo kojem trenutku. ${ }^{35} \mathrm{Tu}$ sv. Alfonz posebno misli na župnike, koji najodgovornije neposredno brinu za duše. Ako budu odbijeni, lako će u tome pronaći razlog da više ne dođu, a tako onda može doći do teških posljedica za vjernike. $\gg S$ jedne strane biskup neka ne gaji familijarnost i preveliko povjerenje prema nekima, kako ne bi bio obmanut od istih ili napadnut od drugih. Ali u susretima treba slušati i postupati sa svima s najvećom prijaznošću. On je otac, zbog čega sa svima mora postupati kao sa sinovima, a ne kao s vazalima. Kaže sv. Jeronim, da biskup koji se služi grubošću prema svojima nije kadar vladati. ${ }^{36} \mathrm{Uz}$ to naš svetac nadodaje da, ako postoji bilo kakva opasnost od sablazni vezano za pojedine osobe, razgovor s takvima treba se obaviti u nazočnosti još dvojice. Također neka se ne poduzima ništa samo na temelju razgovora s jednom stranom, nego neka se sasluša i druga strana ili se preko povjerljivih osoba dođe do pune istine.

Kao posljednje sredstvo kojim se svaki biskup treba koristiti u upravljanju svojom Crkvom sv. Alfonz navodi opomenu. »Također je vlastita biskupova zadaća opomenom uklanjati druge iz grešnog života; na to je obvezan sve do darivanja vlastita života: 'Pastir dobri život svoj polaže za ovce' (Iv 10, 11, op. B. V.). Inače će morati položiti račun Isusu Kristu za sve grijehe koji su se dogodili i koje je on mogao spriječiti opomenom. To je onaj veliki teret kojeg su se plašili sveti biskupi. « ${ }^{37}$

Naš svetac zato daje upute biskupima kako ispravno opomenuti drugoga. Prije svega, opomena treba biti izrečena u ljubavi i blagosti: »Poglavar mora biti dobrostiv i onda kad kori radi pogrešaka. Jedno je koriti odlučno, a drugo oštro. Istina, ponekad je potreban odlučan ukor, posebice ako se radi o teškoj manjkavosti koja se ponavlja i nakon opomene, ali se pritom treba čuvati svake oštrine i srdžbe jer srdit ukor izaziva više štete nego koristi. ${ }^{38}$ Zato opomenu uvijek treba izricati hladne

\footnotetext{
${ }^{34}$ Isto, 91.

${ }^{35}$ Isto.

${ }^{36}$ Isto, 92.

${ }^{37}$ Isto.

${ }^{38}$ Kako ćemo ljubiti Isusa Krista, 54.
} 
glave i smirenih emocija kako se od opomene ne bi prešlo na javni incident, koji onda odvuče svu pozornost i dodatno produbi problem. Nadalje opomena treba biti razborita. Lijek za jednu situacija i za jednu osobu ne mora biti nužno lijek za drugu situaciju i drugu osobu. Osobito to vrijedi onda kad jedna osoba priznaje svoju krivnju i želi popraviti štetu u odnosu na osobu koja tvrdokorno ustraje u svome stavu. Treće, iako je točno da nakon opomene treba vremena da se stvari poprave, to vrijeme ne može biti beskonačno. Opomena ipak mora što brže donijeti plod i zato se taj plod ne može besmisleno odgađati. Zlo valja čim prije popraviti kako se ne bi, poput požara, još više raširilo. Kao četvrto, sv. Alfonz potiče da se opomena učini u tajnosti, pogotovo onda kad je počinjeno zlo skriveno od očiju javnosti jer, kaže naš svetac, »tko je izgubio dobar glas, lako će se cijeli prepustiti u svoj porok ${ }^{39}{ }^{39}$ Stoga $\gg$ kada je to potrebno, opominjimo s blagošću. S blagošću ćemo, naime, više učiniti nego sa svim drugim sredstvima i obrazloženjima. $\mathrm{Ne}$ ispravljajmo druge kad smo srditi jer će upozorenje tada izgledati oštro, bilo zbog riječi bilo zbog načina. Ne upozoravajmo ni onda kada je onaj koja kanimo opomenuti uzbuđen jer ćemo ga tada prije ogorčiti nego osvijestiti $\ll{ }^{40}$

Ako na koncu tako uređene opomene onaj koji je kriv omalovaži samu opomenu, biskup ga treba sa svom odlučnošću kazniti, makar tako riskirao i svoj život. Jer biskup treba više ljubiti pravednost, nego vlastiti život. Sv. Alfonz ne propušta primijetiti da ako krivca ni pravedna kazna ne popravi, barem je tom kaznom dan prodoran primjer drugima za slične situacije. Nadalje, ako se krivac istinski popravi, treba dokinuti određenu mu kaznu. Sv. Alfonz, pozivajući se na sv. Augustina, nadodaje da biskupov osjećaj za pravednost treba biti uvijek združen s blagošću i da je manje zlo pretjerati u blagosti nego u strogosti. Time ukazuje na problem neumjerenosti pojedinih biskupa u izricanju kazni, što opet dovodi do podcjenjivanja važnosti samih kazni. Na kraju naš svetac daje, kako sam kaže, >odličan savjet $\ll^{41}$ biskupima da svoje problematične svećenike, kod kojih se nakon opomene možda i vide naznake popravka, pošalje izvan svoje biskupije i ne dozvoli povratak sve dok se ne prokuša jesu li se doista ozbiljno promijenili i trajno popravili. Problematični svećenici »posebna su vrsta slabih, koji se jako teško popravljaju redovitim sredstvima $\ll .{ }^{42}$

Svoj spis sv. Alfonz završava mislima u kojima još jednom ocrtava temeljnu važnost biskupske službe u Crkvi. Naime podsjeća biskupe da su zajedno s mitrom primili i velik teret odgovornosti vlastite savjesti. Ako se žele spasiti, biskupi moraju oz-

\footnotetext{
${ }^{39}$ Riflessioni utili a' vescovi, 93.

${ }^{40}$ Kako ćemo ljubiti Isusa Krista, 189.

${ }^{41}$ Riflessioni utili a' vescovi, 94.

${ }^{42}$ Isto.
} 
biljno prigrliti neudoban život koji praktički ne pozna opuštanje; život koji je pun križeva i poteškoća zbog velike odgovornosti pred Bogom za povjereno stado. Zato naš svetac razumije zašto su mnogi ljudi, iako sveti, odbijali prihvatiti službu biskupa. Njihova neposlušnost i strah nisu uzaludni jer, kako kaže i sv. Augustin, biskupu je jako teško spasiti se jer je jako teško izvršiti sve dužnosti koje su mu povjerene. $U$ tom kontekstu sv. Alfonz navodi riječi pape Pija V.: »Dok sam bio redovnik, imao sam veliku nadu u svoje spasenje, postavši biskupom počeo sam se jako bojati glede toga, sada, kao papa, gotovo sam izgubio nadu u svoje spasenje. $\ll^{43}$

Ipak, sv. Alfonz ne želi tim zadnjim naglaskom obeshrabriti dobre biskupe, nego ih potaknuti na budnost spram dužnosti koje trebaju obavljati gorljivo i revno. Ako će nemarni biskupi biti kažnjeni velikom kaznom, kako li će tek biti velika nagrada koju je Bog pripravio za dobre biskupe koji su, iako zaplašeni zbog svoje slabosti, $s$ povjerenjem da sve mogu u Bogu koji ih jača (usp. Fil 4, 13) besprijekorno učinili doista sve što su ne samo mogli nego i morali. Na koncu sv. Alfonz obećava »uvijek moliti našega Spasitelja Isusa, i njegovu Presvetu majku Mariju, za sve pastire kršćanskoga stada, kako bi svi bili sveti i kako bi cijeli svijet zapalili ljubavlju Isusa Krista $\ll .{ }^{4}$

\section{Zaključna promišljanja}

U zaključnim promišljanima valja nam se zapitati koja je trajna vrijednost figure biskupa i njegove službe, kakvu nam je po svojim uputama ponudio sv. Alfonz Liguoriji. Prvo, biskupska služba prva je, najvažnija i najodgovornija služba u Crkvi. Zato je svetost biskupa najvažnija svetost u Crkvi, a kriza biskupstva najteža kriza same Crkve. Svojim uputama sv. Alfonz želio je pokazati da jedino sveti, razboriti, blagi, odlučni, gorljivi, prikladno sumnjičavi, jasni u svojim odlukama, dobro upućeni i od razboritih savjetovani biskupi mogu dobro upravljati svojim stadom i tako surađivati s Božjom milošću te iznutra obnavljati Crkvu. S druge strane, mlaki, nezainteresirani, lijeni, pristrani, neupućeni biskupi, koji nesmotreno udjeljuju svoje povjerenje, pa zato loše izaberu svoje najbliže suradnike ili olako zarede nove prezbitere te zaboravljaju na svoja sjemeništa i župe, iznutra nagrizaju svetost cijeoga Božjega naroda kao ni jedna druga krivo obavljana služba u Crkvi.

Drugo, biskup vjerodostojno ispunjava svoje poslanje samo onda kad mu je najvažnija briga spasenje duša, spasenje vjernika. To je temeljni sadržaj njegova poslanja,

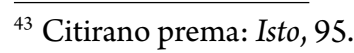

${ }^{44}$ Isto, 96.
} 
koji na poseban način uključuje borbu protiv grijeha. ${ }^{45}$ Borba protiv grijeha, odnosno rast u svetosti i obraćenju, prema sv. Alfonzu, najvažnija je točka u kojoj se sastaju biskupska i prezbiterska služba.

Time je potvrđeno treće što želimo istaknuti - prezbiteri, a među njima posebno župnici, prvi su i najvažniji biskupovi suradnici, odnosno posrednici biskupova dobra upravljanja Crkvom. ${ }^{46}$ Isto se tako biskupova svetost posreduje svetošću prezbitera. Zato sv. Alfonz poziva biskupe da neumorno bdiju nad svojim svećenicima, da ih rado primaju, uvijek ih saslušaju, da im pomognu u dvojbama i problemima kako bi, zapravo, oni njemu bili pomoćnici $\gg$ ne samo time što nešto rade nego «, kako ukazuje Šagi-Bunić, $\gg$ i time što misle, što su redoviti - od Boga mu dani - suradnici u traženju rješenja za različite probleme, u razradi i uobličavanju sadržaja onoga što će se na kraju donijeti kao biskupova odluka $\ll \cdot{ }^{47} \mathrm{U}$ takvom ozračju povjerenja biskup treba poticati svećenike da sami rađaju ideje i rješenja, osobito dušobrižničkih problema.

Četvrto, teološki gledano, prezbiteri biskupu po ređenjem izručuju najmilije što imaju - slobodu svoje volje, vjerujući da tako svoju poslušnost prikazuju samomu Bogu i tako otkrivaju što Bog želi od njih. ${ }^{48}$ Prema našem svecu proizlazi da će Bog biskupe (poglavare) suditi po njihovoj blagosti i razboritosti, a svećenike (podložnike) po njihovoj poslušnosti. ${ }^{49}$ Zato je za sv. Alfonza najvažnije da se biskup prema prezbiterima odnosi posebno blago i razborito. Razboritost se, kako smo vidjeli, ponajviše pokazuje u uvažavanju jedinstvene osobnosti i prilika pojedinoga prezbitera, a blagost biskup treba očitovati osobito onda kad nešto traži od svojih prezbitera. Tada bi biskupi, kaže sv. Alfonz, »trebali radije moliti negoli zapovijedati. Sveti Vinko Paulski veli da poglavari nemaju boljega sredstva od blagosti da bi pridobili naklonost i poslušnost svojih podređenih $\ll^{50}$

Peto i posljednje što želimo istaknuti jest važnost biskupovih odluka. Za sv. Alfonza biskup nužno mora biti besprijekoran (svet u sebi) kako bi bio dobar upravitelj

${ }^{45}$ Katolička Crkva istinska je Crkva i po tome što se u njoj uvijek čuva svijest o grijehu, važnost priznavanja grijeha, kajanja i oproštenja grijeha po sakramentu pomirenja. To je vrlo važna istina za suvremenu obnovu katolicizma, kako je pokazano u: I. RAGUŽ, Grijeh, u: Vjesnik Đakovačko-osječke nadbiskupije i Srijemske biskupije (= Vjesnik) 145(2017.)6, 50-56.

${ }^{46} \mathrm{O}$ prezbiterima kao najvažnijoj biskupovoj brizi vidi vrijedna promišljanja u: D. VUKOVIĆ, Biskup i njegovi svećenici, u: Vjesnik 145(2017.)2, 28-32.

${ }^{47}$ T. ŠAGI-BUNIĆ, Svećenik kome da služi, Zagreb, 2010., 61.

${ }^{48} \mathrm{O}$ poslušnosti u sv. Alfonza vidi više u: Kako ćemo ljubiti Isusa Krista, 135s.; Vježbanje u savršenosti, 114 s.

${ }^{49}$ Tu se slijedi misao sv. Ignacija Lojolskoga. Usp. Vježbanje u savršenosti, 127-128.

${ }^{50}$ Vježbanje u savršenosti, 138. 
(svet u djelovanju). Štoviše, dobro upravljanje kao da prethodi biskupovoj službi propovijedanja i posvećivanja. ${ }^{51}$ Prva i najčešća zadaća biskupa kao dobroga upravitelja jest, gotovo svakodnevno, donošenje važnih odluka - od toga koga imenovati rektorom i odgojiteljima u sjemeništu, koga otpustiti iz njega, preko odluka koga pripustiti ređenju i komu dati ovlast ispovijedanja, do odluka koga izabrati za najbliže suradnike i kako popraviti stanje u župama i samostanima, osobito kako se boriti protiv grijeha. Možemo reći da za našega sveca svaka biskupova odluka mora biti informirana odluka ${ }^{52}$ kako bi bila uistinu autonomna, ispravna i dobra za Crkvu. Informirana odluka jest odluka koja se donosi na temelju informacija koje su istinite, provjerene i potvrđene. Ravnodušnost spram informacija, lijenost u njihovu otkrivanju, oslanjanje samo na neke ili uvijek iste izvore onemogućava dobru odluku. Tada odluka postaje plod manipulacije, a to znači postaje krivom i lošom za Crkvu, iza koje se teško staje.

Pod tim vidom bolje se razumije zašto sv. Alfonz stavlja naglasak na potrebu svojevrsne sumnjičavosti biskupa prema informacijama koje do njega dolaze i zašto savjetuje biskupima da radije izabiru prikladno nepovjerenje nego nesmotreno povjerenje kako laži i poluistine ne bi postale premise njihovih odluka. Nema ničega gorega za biskupovu odluku od laži, i zato biskup mora budno paziti da se laž ne uvuče u njegove odluke, uvijek svjestan da će biti onih koji će se njome pokušati služiti kako bi postigli svoje ciljeve.

Nadalje pod vidom biskupove odluke kao informirane odluke bolje razumijemo i neke naizgled čudne, štoviše, i upitne upute sv. Alfonza, poput one da se biskup pri vizitaciji može koristiti čak i ispovjedaonicom za privatne razgovore ili da se $u$ sjemeništu odaberu najduhovniji i odani prokazivači iz svake spavaonice, koji će u tajnosti redovito izvještavati rektora i biskupa o stvarnom stanju u sjemeništu. Ako uzmemo u obzir cjeloviti duh uputa sv. Alfonza, onda ovdje jamačno nije riječ o poticanju doušnika. Doušnik u središte stavlja sebe i svoj odnos s poglavarom, sve podređuje tomu i zato gubi imunitet na laž, a raste u ulagivanju, laskanju i borbi za moć. Inicijativa je za kazivanjem istine uvijek na njemu. Kao takav doušnik nije dobar čovjek i za našega je sveca je potpuno neprihvatljiv. Najradije bismo rekli da sv. Alfonz spomenutim uputama misli na eklezijalne zviždače, u duhu pojma kojim se danas koristimo za one koji hrabro, slobodno i požrtvovno te uvijek istinito, unatoč velikim rizicima, ukazuju na moralno problematične pojedince i pojave u svojoj in-

\footnotetext{
${ }^{51}$ Rijetko teološko promišljanje o pogrješnim i ispravnim načinima upravljanja župom odnosno biskupijom vidi u: I. RAGUŽ, Svećenik upravitelj, u: Vjesnik 144(2016.)5, 28-32.

52 Ovdje smo se poslužili sintagmom filozofa Rogera Crispa, prema: F. MIJATOVIĆ, Biti zviždač (parezijast): vrlina hrabrosti ili porok ludosti, u: Riječki teološki časopis 24(2016.)2, 265-287., ovdje 276.
} 
stituciji koje su opasne za društvo, a iz uvjerenja da javni interes ima prednost pred privatnim. ${ }^{33}$ Zviždač dakle ide posve drugom dionicom od doušnika.

Međutim radije ćemo se odlučiti za naziv kazivači istine ili osobe istine (parezijasti). ${ }^{54}$ Biskupi dakle trebaju poticati, osobito među svećenicima, počevši od same bogoslovije, klimu kazivanja istine kao vrlo važan vid suradnje s istinom. U središtu osoba istine uvijek je istina, koja je nerazdruživo povezana sa svetošću Božjega naroda $\mathrm{i}$ ljubavlju prema Crkvi. Osobe istine savjesne su, mudre, umjerene, suosjećajne, pravedne, nadasve odvažne, ali su i ponizne, strpljive, bez potrebe da se dopadnu ili da požure učinke svoga kazivanja istine kako bi osjetile osobni uspjeh. Osobe istine, dakako, umiju govoriti i onda kad kazivanje istine ide i protiv njih samih. U klimi kazivanja istine, koja počiva na povjerenju i prikladno računa na tajnost, kazivači istine, odnosno osobe istine, proročki sudjeluju u biskupovoj službi pomažući mu odvažno donijeti informirane, a to znači autonomne i ispravne odluke i za dobro upravljanje Crkvom i za biskupovu jaču osobnu besprijekornost. Zato sv. Alfonz potiče biskupe da mirno saslušaju svećenike, pa i onda kad upućuju žestoku kritiku biskupu. Isto tako zato potiče biskupe da se brinu o dobrim ispovjednicima, ali i da naređuju ispovijedi pred nepoznatim ispovjednikom. Jer tko nije spreman kazivati istinu o sebi pred neznancem u sakramentu ispovijedi, taj uopće nije istinoljubiv, ne zna rasti u istini niti živi duhovnost križa. Spomenimo i to da kazivanje istine nije samo ispunjavanje obveze vlastite savjesti, što je već po sebi jako vrijedno, nego je i odgovor na Božji sveopći poziv na svetost i borbu protiv grijeha, a ne samo na njegovo ukazivanje i razotkrivanje.

Za razliku od doušništva, u klimi kazivanja istine, koja je uvijek klima ljubavi spram istine, inicijativa je redovito na biskupu, on je taj koji propituje i traži istinu. Dakako, to ne isključuje iznimku da i osobe istine katkada preuzmu inicijativu u kazivanju istine.

Već smo više puta istaknuli da je za sv. Alfonza borba protiv grijeha jako važna. Ako se u jednoj Crkvi osjeti da se ništa ili slabo čini u borbi protiv grijeha, i to ponajprije biskup jer je prvi pastir svoje Crkve i jer je obdaren dostatnom milošću i sredstvima za tu borbu, na djelu je očito klima kreirana neinformiranim biskupovim odlukama, a to znači izmanipuliranim i neautonomnim odlukama, ili je na djelu nedostatak hrabrosti da se ukaže na grijeh zbog pomno organiziranog i uspješno proširenog velikog straha od istine. Ili da je, što je još pogubnije, stvorena klima ravnodušnosti spram grijeha, koja je druga strana ravnodušnosti spram svetosti. Zato

${ }^{53}$ Usp. isto, 265-287., u kojem se zviždanje posebno osvjetljava pod filozofskim, odnosno etičkim vidom.

${ }^{54}$ Sustavno teološko poimanje parezije vidi u: I. RAGUŽ, Parezija - Michel Foucault i teologija u dijalogu, u: Nova prisutnost 11(2013.)2, 237-264. 
nas sv. Alfonz sve potiče na istinoljubivost kao važnu krjepost za rastu u svetosti cijeloga Božjega naroda, uvijek počevši od njegovih pastira - biskupa i prezbitera. Takav put nema alternativu i ne boji se križa. Štoviše, kazivanje istine mora računati na križ, a za našega je sveca »najsigurniji dokaz našega ugađanja Bogu ako mirno primamo križeve koje nam Bog šalje $\ll_{.}^{55}$

${ }^{55}$ Kako ćemo ljubiti Isusa Krista, 134. 


\section{ST. ALFONSO MARIA DE LIGUORI'S INSTRUCTIONS TO BISHOPS}

\section{Boris VULIĆ*}

Summary: The office of bishop is the first, most important, and most responsible office in the Church. This makes it the subject of reflection of theologians and spiritual writers, among which St. Alfonso Maria de Liguori (18th century) stands out. After a short biography and an overview of the Church's circumstances of de Liguori's times, the article presents his instructions to bishops on how to govern their Church well. It regards the most important concerns of every bishop (the seminary, ordainees, priests, parish priests, the vicar and close associates, and religious sisters) and the most effective means of a bishop for governing his Church well (prayer, good example, residency, visitations, folk missions, synod, counselling, private audiences, and admonitions). The concluding thoughts show that the figure of the bishop and his office of governing the Church, as described by St. Alfonso, represent a valuable and noteworthy contribution for the modern renewal of bishop's office as well as for the growth in holiness of bishops of Christ's Church, and thus of the whole of God's people. Here, a particular emphasis is placed on the bishop's responsibility to make informed decisions based on truth telling, and the difference is shown between an informant and a person of truth.

Keywords: Alfonso Maria de Liguori, bishops, governing a diocese, the renewal of bishop's office, decision making, truth telling, holiness.

* Asst. Prof. Boris Vulić, Ph. D., Catholic Faculty of Theology in Đakovo, J. J. Strossmayer University of Osijek, P. Preradovića 17, 31400 Đakovo, Croatia, vulic@me.com 